\title{
BETWEEN LEADER-WORSHIP AND MEMBER'S DEMOCRACY: THE CONSUMER CO-OPERATIVES IN THE FASCIST ITALY
}

\section{Entre el culto al líder y la democracia de los socios: las cooperativas de consumo en la Italia fascista}

\author{
TITO MENZANI \\ Università di Bologna \\ tito.menzani@gmail.com \\ FRANCISCO J. MEDINA-ALBALADEJO \\ Universitat de València \\ francisco.medina@uv.es

\section{Abstract}

We analyse the impact of the Italian fascist regime on the consumer co-operative movement. This is of great interest because of the clash between an anti-democratic political culture and a democratic economic culture. We intend to demonstrate that the fascist regime penalized the consumer co-operative movement in various ways. However, a small number of organizations were an exception to this state of events, and paradoxically succeeded, from an entrepreneurial point of view. Some problems — small size, excessive social investments, a more 
political than entrepreneurial vision - were often resolved by the new administrators. This distinction is absolutely essential also in terms of the "legacy" for the consumer co-operative movement after 1945 in Italy.

\section{Keywords}

Consumer co-operatives; fascism; interwar period; Italy; State.

\section{Resumen}

En este artículo se analiza el impacto del régimen fascista italiano en el movimiento cooperativista de consumo, tema de interés ya que supone un choque entre una cultura política antidemocrática y una cultura económica democrática. Se intenta demostrar que el régimen fascista penalizó al movimiento cooperativista de consumo de varias formas. Sin embargo, un reducido número de organizaciones constituyeron una excepción a este fenómeno y, paradójicamente, tuvieron un considerable éxito en su funcionamiento desde el punto de vista empresarial. Algunos problemas — tamaño reducido, excesiva inversión social, una visión más política que empresarial - fueron resueltos de manera frecuente por los nuevos administradores afines al régimen. Esta configuración del movimiento durante el periodo fascista también fue absolutamente esencial en términos de «legado» para entender la evolución del movimiento cooperativo de consumo italiano después de 1945.

\section{Palabras clave}

Cooperativas de consumo; fascismo; periodo de entreguerras; Italia; Estado. 
I. INTRODUCTION. II. THE EVOLUTION OF CO-OPERATION IN ITALY. III. VIOLENCE AND THE ANTI-CO-OPERATIVE CULTURE. IV. CONCLUSIONS. BIBLIOGRAPHY.

\section{INTRODUCTION}

In the nineteenth century, during the industrialization and spread of the liberal economy, several theories emerged as a reaction to the social consequences of the new market society. These theories postulated that the co-operatives were a formula via which to mitigate what was termed "the social question": low wages, unequal distribution of income and wealth, deficiencies in public sanitation cause by the urbanization process, etc 1 .

The ideological origin of co-operation as a lever for social change was in utopian socialism; in this context, we should note especially Rowert Owen in Great Britain, who considered that the way to achieve social welfare was through a community organization that was itself based on co-operation and collective ownership. In France, other utopian socialists also favoured co-operation, such as Charles Fourier, who proposed phalansteries; Louis Blanc, who considered that the industry should be organized in co-operative bases within social workshops under the direction of the State; or the anarchist Pierre-Joseph Proudhom, who suggested that society should be organized in a federation of workers' associations based on mutualism and co-operation, (and thus that the State would disappear).

Marxists revised the role of co-operatives and stated that reproducing the methods of capitalism did not help socialism and did not serve to answer the social question. The socialist movement initially had grave misgivings about the formation of these entities ${ }^{2}$. However, after the dissolution of the First International (1876), more pragmatic revisionist theories emerged, such as Fabianism in England, which favoured a gradual social improvement of the working class though the action of political parties, trade unions and co-operatives that were located within the capitalist system. Later, the Catholic Church also began to consider co-operatives as a kind of formula that could

Thompson (1966); Williamson (1991), and Wrigley (1990).

2 Brazda and Schediwy (1989). 
be used to solve the social question; this change was due to the encyclical Rerum novarum of the Pope Leo XIII (1891).

The co-operative movement originated in Great Britain in 1844, with the creation of the Rochdale Equitable Pioneers Society in Manchester County. The fact that it rapidly spread to other English regions and European countries was due to the Holyoake's writings about this institution ${ }^{3}$.

Consumer co-operation is a form of enterprise that is universally considered democratic. Co-operatives are owned by shareholders who, on an equal basis - one member has one vote — decide on the future of their organization. Consumer co-operation was initially politically neutral. During the period of impressive development that it subsequently experienced, this was, however, often set aside. In continental Europe, co-operatives were promoted in connection with socialist, christian and democratic liberal traditions. In every case, however, these were political cultures which recognized the value of democracy (albeit from different perspectives), and as such they did not have any difficulty in interacting with the co-operative form of business ${ }^{4}$.

In the case of Italy, consumer cooperatives emerged during the late nineteenth century, in all three of the political traditions (socialist, christian and democratic liberal). However, only the Socialist cooperatives were to become a widespread movement that was active in most of the national territory. The main advocates of this model - e.g. the Marxists Camillo Prampolini and Antonio Vergnanini - believed that the consumer cooperative should be at the service of the popular classes and receive the profit gained by the shopkeeper. In addition, as suppliers, they had to be privileged agricultural, agrofood and manufacturing cooperatives, if they were to support other parts of the movement. It was a utopian project of "integral cooperation", which was never realized, but which was an ideal model to which to aspires.

According to the historiographical evidence, the development of these entities during the interwar period was unequal mainly for two reasons: how the post-war period was managed in each country, and the new political and social conditions generated by the fascist regimes.

Italian fascism came into being in 1919 as a radical and nationalist, but also anti-Bourgeois and anti-monarchic, political movement, which later evolved to embrace anti-socialist ideas. Between 1919 and 1922, fascists were organized into paramilitary groups, and violently attacked unions, left-wing parties and cooperatives, killing or injuring thousands of political opponents.

\footnotetext{
3 Holyoake (1857).

4 Zamagni and Zamagni (2010).

5 Battilani (2005).
} 
Concurrently, they presented themselves as a reactionary movement that was working in increasing harmony and was able to protect the traditional order from the threat of a revolution similar to that of 1917 in Russia. In 1922, the fascist leader Benito Mussolini was given by the king the task of forming the new government of the country. Through this institutional role, over the course of a few years, he transformed the weak Italian democracy into a dictatorial regime ${ }^{6}$.

In European democracies, the consumer co-operatives continued to spread and they went through a process of concentration (through mergers and the creation of regional federations). In this context, the "technocrats" played an important role in the management of these entities. They focused more on economic efficiency than internal democracy, which had been previously one of the main features of traditional consumer co-operatives. This new focus is notable especially in the Scandinavian countries ${ }^{7}$, in Finland, in Germany during the Weimar Republic and in Switzerland, but not so much in Great Britain or France, where there were more traditional and politicized entities $^{8}$. How did these democratic organizations adapt themselves to totalitarian regimes?

This paper examines the impact of the Italian fascist regime on the consumer co-operative movement. It is a matter of great importance because this movement is related to the clash between an anti-democratic political culture and a democratic economic culture. We will demonstrate in this work that the fascist regimes penalized the consumer co-operative movement, because co-operation was considered a model far removed from authoritarian planning, because it was connected to anti-fascist ideologies, and finally because one of the groups that supported fascism was the small shopkeepers (these were in direct competition with the retailing co-operatives).

Despite this, consumer co-operation survived in Italy, whereas in Germany it was obliterated only in 1941 in the context of the war. Not only did co-operation survive, but in Italy it also exhibited some elements of innovation and modernity from a business point of view, which seemed to be in marked contradiction to the overall panorama. The reason for this rests on the fact that in order to survive, some societies adapted to the new

6 Bosworth (1998).

7 The important role of the consumer co-operatives helped the positive vision of this region in countries such as the United States. The Nordic countries were considered a successful example of the "middle way" between capitalism and socialism in the turbulent decade of 1930. See Hilson (2013).

8 Brazda and Schediwy (1989); Friberg et al. (2012), and Furlough (1991). 
institutional and organizational paradigm. Thus, even if they became distorted from a co-operative point of view because the oligarchic structure replaced democracy, they gained in terms of economic efficiency and their technical-organizational abilities. For example, the Italian consumer co-operative movement created a national consortium in 1927. Moreover, fascism in Italy and nazism in Germany had a controversial and non-uniform approach to co-operatives. Some consumer co-operatives were simply closed or strongly impeded. Others were placed under the management of men close to the regime, in order to control these organizations and to defuse their political drive. The regime sometimes played an entirely negative role, impoverishing the co-operative and using it for patronage purposes, whereas in other areas entrepreneurial activity was developed in a more technical sense, with modern management being introduced and greater efficiency resulting. It should be acknowledged that prior to this the consumer co-operatives had suffered from some problems - their small size, excessive social investments, and a more political than entrepreneurial vision - which were often resolved by the new administrators or by the old managers who had aligned themselves with the new course.

For a long time, Italian co-operation during the fascist period and German co-operation under the nazis were considered of little interest because it was believed that the co-operative movement had been defeated and "compressed" 9 . This view stemmed primarily from the judgements of anti-fascist co-operators after 1945, who were influenced by ideological visions or strong emotions. More recently, quantitative analysis has refuted this historiographical statement, and it has been demonstrated that many co-operative sectors were not handicapped by fascism in terms of turnover or employees ${ }^{10}$.

In summary, we want to demonstrate how the consumer co-operatives as a whole were penalized from both a quantitative and qualitative point of view $^{11}$. However, a small number of organizations were an exception to this state of events, and paradoxically they succeeded and even benefitted in term of business from the new cultural horizon. This distinction between failure and success - at least in the case of Italy — is absolutely essential also in terms of the "legacy" of the fascist period for the consumer co-operative movement after 1945.

\footnotetext{
Basevi (1953).

10 Menzani (2009). See also Battilani (1999) and Prinz (2017).

11 A later example like Spain during Francoism also seems to demonstrate this in relation to the consumer co-operatives. See Medina-Albaladejo and Pujol-Andreu (2014) and Medina-Albaladejo (2017).
} 
This article is divided into four sections: after the introduction, in the second section, we explain the evolution of consumer co-operatives in Italy from a quantitative point of view. In the third section, we establish the relationship between co-operatives and the Italian fascist regime. The article closes with conclusions.

\section{THE EVOLUTION OF CO-OPERATION IN ITALY}

In Italy a large co-operative movement, which was well-rooted in working-class society, had to operate within a truly anti-democratic and illiberal regime. The following paragraphs will review the quantitative evolution of the consumer co-operative movement during the Interwar Period, and then the different qualitative paths that characterized this evolution. This period was characterized by the opportunistic and parasitic exploitation of the co-operatives by the institutions (though there were some exceptions to this state of affairs).

The statistical treatment of the subject is difficult for two reasons. After the First World War, Italian consumer co-operatives were not represented by a single organization, but were politically divided between several umbrella organizations. As a result, it is necessary to consider the information from every single organization, and these sources do not always survive. The second problem concerns the statistical information that is necessary to paint a sufficiently broad and reliable picture, which must not be limited to just the existing co-operatives, but which should consider also some indicators of their size, such as number of members, employees, social impact and the turnover.

Unfortunately, as Italian historiography has underscored several times, this information is not always available, and therefore the statistical reconstruction must allow for some lacunae which may be significant. Aside from these difficulties, however, the data that we have allow us to undertake certain significant evaluations.

Italian co-operation, and with it the entire consumer sector, underwent intense development in the first decade of the twentieth century, which is not called the "golden era of the movement" by chance ${ }^{12}$. In a context of industrialization and urbanization, these co-operatives offered easier access to basic foodstuffs and cultural, social and educational services, which compensated for the still weak presence of the State in this field. The development of Italian consumer co-operatives was consistent with the European general trend ${ }^{13}$

\footnotetext{
Zamagni and Fornasari (1997): 82.

13 Brazda and Schediwy (1989).
} 


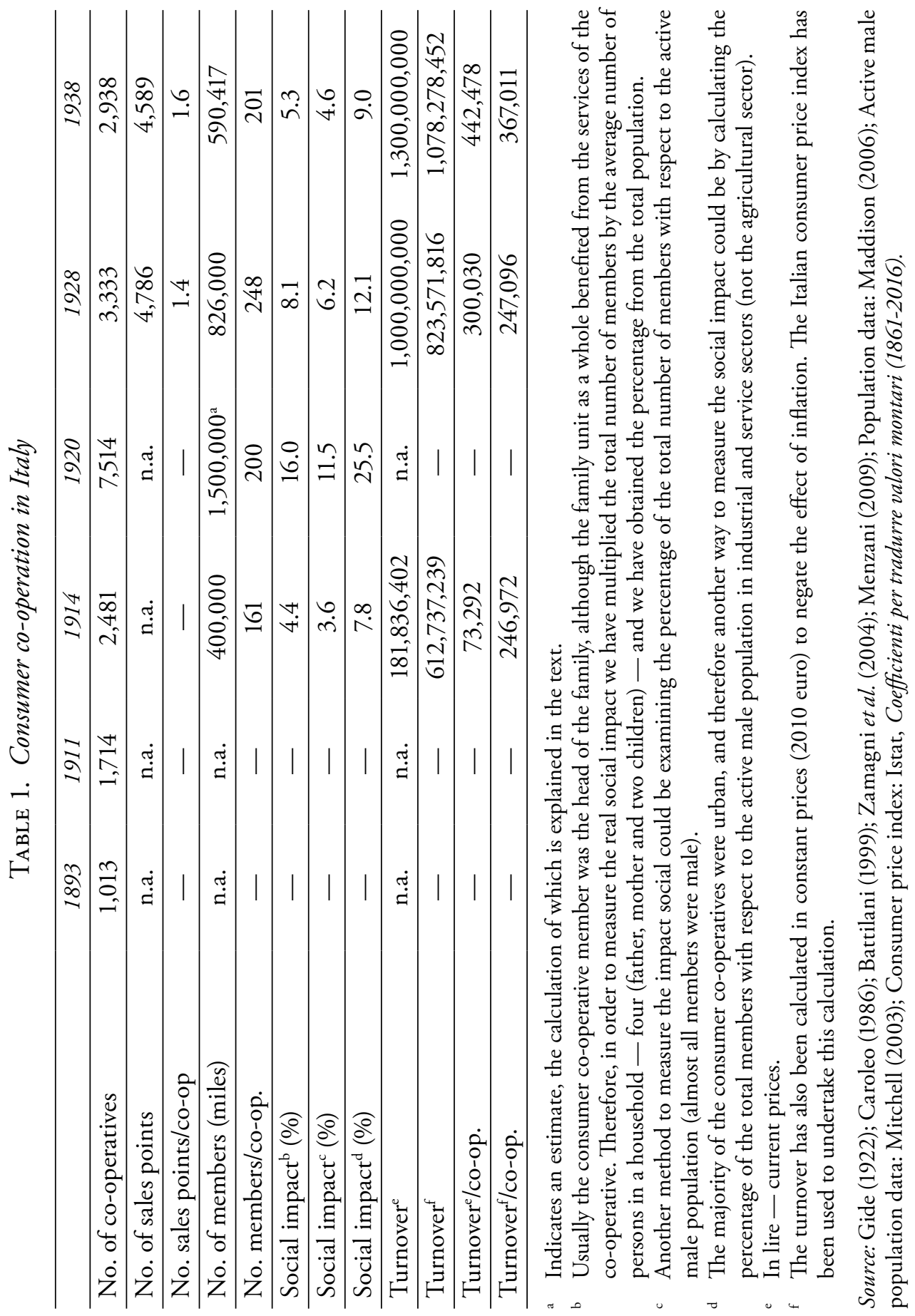


- they developed as a response to the social problems caused by the new market economies ("the social question"): low salaries, unequal income distribution and an intense shortage of basic services ${ }^{14}$.

On the eve of the First World War, 2,481 consumer co-operatives were operating in Italy ${ }^{15}$. The majority of these enterprises were single shops, while the large businesses which operated with several sale points in a provincial market were few, and were located mainly in Piedmont and Lombardy ${ }^{16}$. Italian consumer co-operatives had approximately 182 million lire and 400,000 members in total ${ }^{17}$.

The size of the Italian co-operatives was smaller than in other countries such as the United Kingdom, where these entities had more than 2,000 members per co-operative ${ }^{18}$, compared to little more than 160 members per co-operative in Italy. That is, in Italy, the co-operative movement was much more atomized, and the social impact was less than that in United Kingdom, Switzerland, Scandinavia, France or Germany, due to the fact that more than 4 per cent of the total population benefitted from a co-operative and almost 8 per cent of the active male population in the industrial and service sectors were members of these entities (Table 1).

After the First World War the number of consumer co-operatives rose greatly all over Europe, reaching 7,514 entities in Italy. This increase was also a result of the high cost of living and problems with food procurement, as well as the annexation of areas with high levels of co-operative activity such as the Trentino (a border area that the Austro-Hungarian Empire had transferred to Italy after the Great War). The catholic co-operative movement had also expanded; in 1919 it founded its own national umbrella organization, the Confederazione delle Cooperative Italiane (Confederation of Italian Co-operatives) in opposition to the Lega Nazionale delle Cooperative (National League of Co-operatives), which had socialist overtones. Most of these co-operatives continued to operate exclusively locally, and thus we can suggest that almost all the new organizations were single shops.

If we consider that the size of the Italian consumer co-operatives was approximately 200 members per society, it is likely that the Italian consumer co-operatives of 1920 would have had 1.5 million members. Therefore, the social impact could increase to affect 16 per cent of the total population and

\footnotetext{
14 Thompson (1966); Williamson (1991) and Wrigley (1990).

15 Gide (1922): 49.

16 Setzer (1989).

17 Gide (1922): 49.

18 Gide (1922): 49.
} 
25.5 per cent of the active male population in the industrial and service sectors - the highest levels until that time, but still quite a lot lower than the main European countries. It is more difficult to estimate the overall turnover, and this will not be attempted here.

The advent of fascism involved a significant reduction in these numbers. Benito Mussolini and the fascists took four years to transform Italian democracy into a nationalist dictatorship. Thus, in 1928, two years after the definitive closing of all the representative organizations and the establishment of the Ente Nazionale Fascista della Cooperazione (National Fascist Agency on Co-operation - ENFC), the Italian co-operative movement had 3,333 consumer enterprises, with 4,786 points of sale and 826,000 members and overall sales of 1 billion lire. Ten years later, on the eve of the Second World War, these numbers had undergone another small contraction: 2,938 businesses, with 4,589 shops and 590,417 members, who produced sales of 1.3 billion lire. The social impact decreased to 5.3 per cent and 9 per cent respectively.

In less than 20 years, therefore, the Italian consumer co-operative was marked by a collapse in the number of entities from 7,500 to 3,000 businesses, which also created an equally strong drop in the number of shops and members, from 1.5 million to a little less than 600,000. The size (members per co-operative) of these entities stayed more or less equal, but the sales at constant prices per co-operative appear to be significantly higher in 1938 , and this rise was also due to the overall increase in individual consumption during the interwar period. Until 1928 the turnover at constant prices per co-operative remained steady, but ten years later had increased by 49 per cent. These figures emphasize a process of concentration, which also likely occurred in the rest of the European countries ${ }^{19}$. There were fewer entities and members, but they sold more and the number of sales points per co-operative grew.

\section{VIOLENCE AND THE ANTI-CO-OPERATIVE CULTURE}

Fascist aversion to consumer co-operation stemmed from two principal elements, one of which was of an idealized nature and one which was more concrete. Co-operative business was founded on the principle of members' democracy, and in most of Europe it was connected to leftist or anti-fascist political cultures. Furthermore, in the specific case of the consumer movement, the

19 Brazda and Schediwy (1989). 
direct competitors were the private shopkeepers who constituted one of the social bodies which formed fascism ${ }^{20}$.

The fight against co-operation involved four different strategies. The first two did not require fascism to gain power. These were a defamatory and disparaging press campaign (achieved through the propaganda of rightwing newspapers) and a series of violent attacks, in blackshirt style, which aimed to physically damage the co-operatives. For example, in Friuli-Venezia Giulia, a region in north-east Italy, fascists attacked and injured dozens of co-operators during $1921^{21}$. The other two strategies could only be implemented from a position of institutional responsibility. This involved approving a series of laws against co-operation and imposing on co-operatives, by means of pretexts and pressure, managers who were ideologically closer to fascism.

Anti-co-operative propaganda was a characteristic of most European nations in the first two decades of the twentieth century $y^{22}$, and was promoted not only by fascist groups, but also, more broadly speaking, by liberals and conservatives. The economic success of the co-operatives generated fear and resentment among many middle-class groups, in particular shopkeepers, land owners and industrialists. The idea had matured that co-operation represented an economic model which drew its energy from an illiberal intertwining of public and party power, strengthened also by the fact that the co-operative enterprises were admittedly often inspired by socialist or catholic ideology. In practice, from a right-wing point of view, the co-operatives were organizations which exploited political knowledge in order to gain favours in terms of contracts, licences or tax benefits ${ }^{23}$.

In Italy, for example, a controversy arose concerning the "red co-operativism octopus of the State" 24 , which included among its protagonists famous intellectuals such as Maffeo Pantaleoni. In correspondence with Charles Gide, he wrote: "you ask me why economists do not like co-operatives; we do

20 Menzani (2009).

21 Bof (1995).

22 See the monographic issue La cooperazione italiana, 2 (2009) that analyses the history of the movement in Europe during the interwar period.

23 Killingback (1988).

24 "Cooperativismo rosso piovra dello Stato" is the title of a polemical written by Giovanni Preziosi, then republished in the volume of the same author: Uno Stato nello Stato. La Cooperativa Garibaldi della gente di mare (Preziosi, 1922), with a preface by Maffeo Pantaleoni. See also Zavaroni (1987): this is a monographic issue, and Boccolari and Ferretti (1987). 
not like them because they have stolen hundreds of millions from the State, and because they are the most shameful thieves that I have ever encountered in the world of business" 25 . In his other works, Pantaleoni did not shrink from attacks on "socialist, communists, Bolsheviks, demagogues of low social bases, of low-life, of deadbeats", and defined co-operatives as "cases of founding fortresses or strongholds of Bolshevik bandits, placed precisely where the economic activity of the country must be carried out through forced paths, and therefore can effectively be extorted" 26 .

This type of liberal tradition, which was the enemy of State intervention in the economy and therefore was in opposition to collaboration between local governments and co-operatives, provided fascism with a wide theoretical frame of reference. In Italy and Germany the supporters of Mussolini and Hitler readily accepted the arguments against co-operatives that had been expressed previously by the conservatives, whose goal was to generate anti-co-operative public opinion and a general understanding of the harsh measures which would be taken against the movement. In Italy, Dino Alfieri, co-director of the Exhibition of the Fascist Revolution (November 1928), talked of co-operation which in the past was "completely warped" and "enslaved to the socialist party", which was managed by those "Italian Reformists", who with their "ambiguous mentality" could mostly be considered "the greatest corrupters of the political character of our country" ${ }^{27}$. Other pro-fascist scholars followed this same line. "The co-operative", wrote the deputy secretary of the Ministry of Corporatism (Ministero delle Corporazioni) Giuseppe Bottai, in 1927, "during the years the memory of which is still sinisterly vivid, too often served to propitiate, for electoral purposes, subversive trade unions, thanks to various forms of parasitism" 28 . According to the fascist co-operator Rosaria Labadessa:

Of the old co-operative experiments those best known to the public are, naturally, the worst; and from these the public has learned that the co-operative is a business which can be run without capital, and without risking anything, [...] which continues because it is protected and pushed by some politician, or because there is an active and cunning president or director, interested in keeping the show going for as long as possible ${ }^{29}$.

\footnotetext{
25 Quoted by Fay (1939): II, 197.

26 Pantaleoni (1922): 11, 17.

27 Alfieri (1929).

28 Speech by Giuseppe Bottai (26 May, 1927) quoted by Briganti (1978): 46-47.

29 Labadessa (1931): 7-8.
} 
Blackshirt violence and fervour rapidly spread following these verbal controversies. With widespread institutional support, fascist violence against co-operatives and its members increased. These attacks were justified by the need to block the subversive perspectives which stemmed from the Biennio Rosso (Two Red Years, 1919-1920) ${ }^{30}$. Mussolini and his collaborators understood that the co-operative organization represented a decisive connection between mass organizations and society. In fact, the co-operative enterprise was perceived as a political entity as well as an economic one, which inserted itself, together with the rural leagues and the trade unions, into the collection of structures with socialist, catholic and liberal-popular overtones which permeated contemporary society and which represented an irreplaceable pivot between parties and citizens.

In fact, various political forces exploited these organizations to increase their own popularity: they targeted individuals and aimed to meet their needs and be part of their aspirations by coordinating propaganda and information. For fascism, the breaking of these links signified a crisis in the opposing forces, and therefore this separation or break was an essential part of conquering institutional power. During the early 1920s, hundreds of co-operatives were the target of assaults, and these were the prelude to the subsequent control of the co-operative movement ${ }^{31}$.

In Germany, violence against the co-operatives was less pervasive and mostly occasional ${ }^{32}$. However, we must bear in mind that Mussolini gained power with a type of coup d'état, which was idealistically represented through the image of the march on Rome, and that Hitler became Chancellor through election and as such did not have such a great need for violence and intimidation. Moreover, anti-Semitism was a strong feature of nazi violence, and the attacks against the labour movement were less important in Germany than in Italy.

Once fascism gained power, the strategy towards consumer co-operatives changed rapidly. Violence diminished tremendously or ceased, and propaganda also became an accessory instrument. A more institutional approach was now favoured: for example, the launching of anti-co-operative legislative measures and the placement of men close to the party among the executives. One such instance of forced resignations was when some of the biggest Italian worker co-operatives in construction and brick production,

\footnotetext{
30 Fabbri (2009).

31 Franceschelli (1949).

32 Kurzer (1997).
} 
which were located in Bologna, were forced to lay off their technical managers and were then forced to employ fascist directors ${ }^{33}$.

All this went hand-in-hand with a new economic theory of co-operation, the formulation of which was complex, controversial and, ultimately, disastrous. The basic idea was to cut all ties with the recent past and to rediscover purity in the origins of co-operation - purity which had once existed but then was besmirched by marxist and christian democratic interpretations. Everything was to be expressed in nationalistic terms, to encourage a sui generis form of "fascist co-operation". Consumer co-operation was first of all rethought in a more inter-class sense, but all the other formulations were veritable oxymorons because it was never possible to reconcile members' democracy with leader-worship.

The ENFC senior official, Cesare Gheduzzi, for example, wrote some remarks which clearly reflected how the fascist embodiment of the co-operative was attempting to harmonize democracy and leader-worship through the concept of "organicism", a doctrine which supported the idea of the diversity of the people and which was based on each individual having their own specific role as an organ in the body. In a book analysing the case of Sweden, which was very important at that time, he highlighted how in this Nordic country co-operation was pervasive and deep-rooted in communities:

The best results are obtained when the members [that is the shareholders] show serious interest in the way in which they are administered, [and] worry especially about electing and controlling the executive bodies, to whom they give moreover the greatest freedom of action. [...] It is first necessary to find and then train men who, in the different branches of the movement, not only enjoy the trust of the members and carry out the position assigned satisfactorily, but who also have the gift of being a driving force of the people, in order to direct the co-operators along that path that only their intuition can designate as the best ${ }^{34}$.

Similarly to the events in Italy, consumer co-operation in Germany was also restructured and re-organized, but not immediately destroyed. This caused various influential forces in German society which were close to nazism (or in any case were conservative) to protest through certain shopkeepers' associations against those "hard and pure" nazis who considered the democratic-co-operative logic irreconcilable with leader-worship (Führerprinzi). nazism preferred to take over entrepreneurial heritage rather than

33 Peruta and Varni (1989).

34 Gheduzzi (1934): 39. 
destroy it, through a policy of "alignment" (Gleidischaltung) with the totalitarian State; from an ideological point of view, however, it tried to insist on the bonds between community and co-operative ${ }^{35}$.

The attempts to conceptualize a non-democratic co-operative elicited few results, except perhaps for the formulation of the one-to-one relationship between leader and people. However, this relationship could perhaps have functioned in the huge meetings of Mussolini, but would not have worked for the members' meetings (during which the president read and explained the financial statement); fascism never managed to eradicate the concept of democracy from co-operation.

In Italy and Germany, there was a dichotomy between "fascist pseudo-co-operation" and "pseudo-fascist co-operation". Both involved a certain distortion of the co-operative principles, and the use of categories derived from liberalism in order to create a co-operative ideology which not only was not very original, but which did not even involve much fascism. In fact, given that the fascist principles and those of co-operation were incompatible - if only because of their different opinions on democracy - there would have been fascist co-operation which in fact was no longer a form of co-operation, or a real co-operation which was in fact not fascist ${ }^{36}$. The type of co-operation would have depended on the vigour with which the regime put its own mark on the enterprises. Therefore, where there was fascist ideology there was no co-operation, and where there was co-operation there was no fascist ideology.

These ideological oxymorons were reflected in the legal approach. In Italy, the work of "legal revision" was based on the creation of three different types of consumer co-operative (depending on the context). The first type of co-operative was composed of a joint-stock company, based on Articles 219 and 228 of the Codice di Commercio (Commerce Code), which was open to the public and which paid dividends in the forms of both stock (utile) and refund (ristorno). The second type of co-operative complied more strictly with the non-profit ideal of the co-operative, and thus the share quota was not productive and only the ristorno was recognized. The third type of co-operative was similar to an independent institution or agency, and these were under the total or partial patronage of public agencies and referred to the similar experiences accrued during the First World War, at contingent moments ${ }^{37}$.

35 Dowe (1988) and Fairbairn (1999).

36 The most important books that supported the idea of a fascist cooperation are: Labadessa (1928); Pagano (1930); Focarile (1930), and Lama (1933).

37 Menzani (2009). 
In general, the preferred model was the second one because the co-operative association resembled "a large family", and because purchases and distributions were closely connected with welfare practices. In fact, the moral aim of providing mutual aid, education and better hygiene was one which was also held by consumer co-operatives and should be linked to propaganda: for example, propaganda through various initiatives such as seaside and mountain colonies for the children of members. Thus, the role of moderating consumer prices was reduced, although the co-operatives and their consortiums had done this during the pre-fascist era, as part of their efforts to protect members and customers in general. This ability to moderate was replaced by forms of welfare which were of very different scopes and significance ${ }^{38}$.

In terms of legislature, the German consumer co-operatives were penalized more than those in Italy. In 1933, it was established that the dividend paid by the consumer co-operatives could not exceed 3 per cent of the turnover, and that "this provision was not only aimed at limiting professional freedom, but also questioned one of the first principles of consumer co-operation, namely the distribution of the surplus among the member". Then, in 1935 a specific "law on consumer co-operatives" eliminated or privatized the co-operatives which were in greatest difficulty. This affected fewer than 100 societies, and the means of control were intensified for those which remained: for example, troublesome staff were replaced with members of the nazi party, and the most restless co-operatives were forced to merge with the already "standardized" sister enterprises ${ }^{39}$.

The management of the consumer co-operatives by fascist administrators, those who were close to fascism, and those who were not fascists but were intimidated by the regime deserve some specific comments because reality and theory were very different. We have shown that in many cases the participation of pro-fascist managers was negative, fraudulent, and parasitic or patronage-type administrations, but it is also true — paradoxically — that in certain cases there were successful developments from a business performance point of view.

The vast majority of consumer co-operatives which joined ENFC were the products of the "fascistization" of existing businesses, mainly socialist or catholic; in contrast, the number of consumer co-operatives created after Mussolini came to power was small, and these co-operatives were mostly founded on the initiative of ex-combatants. Therefore, the Italian consumer

38 Degl'Innocenti, (1981). See also Biagi (1927); Piemontese (1928), and Labadessa (1933).

39 Ditt (1986) and Novy (1988). 
co-operatives were governed and managed by pro-fascist administrators, and had a social base which still partly had an anti-fascist orientation. In other cases, the old management remained, having in some way complied with the new political situation and accepted various compromises and certain impositions $^{40}$.

Especially in those associations in which administrators close to the regime had been placed, the distance between these new managers and the old social base was very clear. A strong relationship matured, and the authoritarian impositions, which very often had originated from a private-law concept of co-operation, almost completely cancelled out the democratic mechanisms. Fascism debased the participatory instruments and emphasized the powers of those individuals - such as the technicians or the executives who had been placed in roles because of their ideology. In certain cases they started to expropriate the property of consumer co-operatives: the assets, the office or other properties could be sold at favourable prices to people outside the co-operative, and it was not a coincidence that those favoured were close to fascism or were related to the new blackshirt administrators. In various provinces there was "legalized usurpation, conducted without outcry, but with equally annihilating determination: [...] of the forced sales, the compulsory dissolutions, the fake donations, caused by illegal pressure and threats and [...] supported by notarial deeds, minutes of assemblies, [...] by liquidating decrees of complaisant prefectural authorities"11.

Within the co-operatives in which fascism had achieved substantial and effective control, the members and the employees who had most strongly expressed - or continued to express - anti-fascist tendencies were harassed in various ways, from demotion down to expulsion under any pretext. Also, at this stage, supporters of the regime were granted paid positions in co-operatives $^{42}$.

In the province of Ravenna, for example, where the consumer co-operative movement was a protagonist in the local market, fascism suppressed almost all the shops through various stratagems. Only a couple of the least important were left open, to the benefit of the private shopkeepers who thus found the road cleared of troublesome competitors ${ }^{43}$. Some consumer

40 Other managers, such as Angiolo Cabrini, sincerely conformed to fascism: Fabbri (1972).

$41 \quad$ Arbizzani et al. (1991): 15.

42 Storchi (1988).

43 Casadio (2009). The case of consumer cooperation in Trentino is also important: Leonardi (1991). 
co-operatives were closed down by local authorities after a fabricated inspection; others were accused of swindling the members, put under temporary receivership and then dissolved. This "reprivatizing axe" ${ }^{\text {"4 }}$ — as this operation was defined - represented one of the hardest blows to the Italian co-operative movement.

In 1923 the Prefect of Turin divested the Associazione Generale Operaia (General Labour Association) of power and placed a commissar at the wheel of the historic Alleanza Cooperativa Torinese (Turin Co-operative Alliance) - the first consumer co-operative in Italy. The same fate befell the Unione Cooperativa di Milano (Co-operative Union of Milan), the largest and probably best-organized Italian consumer co-operative. Controlled by fascists from 1923, when some men were placed on the Board of Directors, it was subsequently placed under the administration of an external commissioner. An important measure taken by the new management close to the regime was the dismissal of many anti-fascist employees, who were replaced by persons close to the regime. Moreover, the fascists caused a reduction in turnover by closing those points of sale that were most troublesome to the shopkeepers, who were the most important competitors in the retailing sector ${ }^{45}$.

Various cases of this kind were recorded in Germany as well, though over a much shorter time span (1933-1941). The start of the Second World War and the change in top officials at the Ministry of the Economy accelerated the decline of the German consumer co-operatives. In 1941 an ad hoc law decreed their definitive dissolution, starting in 1942. The businesses were liquidated and the members were reimbursed a small part of the shares, whereas the rest of the equity - human resources, points of sale, financial liquidity, etc. - went to the "Gemeinschaftswerk der deutschen arbeitsfront" (the Company of the German Labour Front), which was controlled by the State. The procurement mechanism, which had been duly restructured, was used to support the war effort. Thus, the aim which had prescribed a few years previously was dramatically realized. This aim was that the consumer movement should not only benefit the members, but was also subject to the greater interests of the nation ${ }^{46}$.

It should be noted that within this very negative picture there were certain more positive elements from a business performance point of view. The most interesting element was the merger - either forced or incentivized — of small consumer co-operatives that operated within the same geographical

44 D'Attorre et al. (1988): 100.

45 Nejrotti $(1984,1986)$.

46 International Co-operative Alliance (1940), Kluge (1991). 
context. These were mostly businesses which had started on the initiative of different leaders or management groups and which until that point had preferred to compete rather than collaborate. Unification meant achieving economies of scale, with a greater critical mass; a more advantageous level of trade; a cut in the fixed costs; and a single president, a single director and a single Board of Directors. The managers' resistance to these mergers was often swept away by fascist authoritarianism. In 1929, for example, the fascist co-operator Tullio Giumelli set out an ambitious programme for the reorganization of the sector which, owing to the nostalgia for the early origins of Fascism and the compromises made during its concrete application, however, had a modernizing impact:

This is how the consumer co-operative should organize itself in Italy; suppression, even violent, of the small and useless organizations: in the towns, merger of the existing co-operatives; suppression of the sectoral co-operatives (tram drivers, railway workers, soldiers); alliances and mergers with municipal organizations which are only a remnant of the baggage of war. Imagine what a different influence co-operation in Milan would have if instead of the fifteen or sixteen enterprises of all kinds there was a single body with three hundred thousand members capable of selling several hundred million food items. [...] And in the rural areas: what a different influence would a single co-operative body have in Reggio Emilia with sixty branches instead of sixty consumer co-operatives spread over every "Villa" with an accumulation of administrators one more jealous than the other of his small business ${ }^{47}$.

This programme was only partially carried out because in various provinces it faced opposition in the form of the fears of those shopkeepers who perceived the entrepreneurial modernization of the sector as a threat to their profits. They had a strong political influence since they were among the principal supporters of the rise of fascism. If we note that in Bologna, Reggio Emilia and Genoa the mergers between the consumer co-operatives actually occurred and can be judged positively with regard to business performance, we should also note that in other areas they remained on paper. In the municipality of Pavia in the mid-1930s there were ten different consumer co-operatives, whereas in Ancona - but also in Vigevano and Modena — eight small self-governing associations competed, each of which was located in a different district ${ }^{48}$.

47 Giumelli (1929): 87-90.

48 Menzani (2009). See also Zamagni (1981). 
All this explains why the number of co-operatives in Italy dropped from 7.514 to 2.938 in the period 1920-1938, but the turnover at constant prices per co-operative grew 49 per cent in comparison with 1915 levels (Table 1). There were fewer entities, but they sold much more than before. These data confirm that the fascist period prompted a concentration process for the consumer co-operative movement, as was also the case in other European countries under the leadership of technocrats, according to Brazda and Schediwy ${ }^{49}$.

In Germany, the process of forced concentration was implemented with greater conviction, at least where the consumer co-operatives were not closed as a matter of course. A study by Kuno Bludau has demonstrated how the economic impact of nazism on the consumer co-operative movement had a twofold effect: the termination of various entities and, in contrast, the increasing efficiency of many others (this increase in efficiency was due to the reorganization, i.e. the mergers of small businesses). As a rule, however, these economic benefits were not particularly long lasting - they were basically confined to the second half of the 1930s - because the outbreak of the Second World War meant this collective entrepreneurial experience was abruptly interrupted. The benefits were much more limited than in Italy because the final aim of the nazi regime was the destruction of the co-operative movement. A few entities benefitted from State action, but the movement lost around half of its members, social impact and turnover, until it was finally destroyed during the war $^{50}$.

Another important element was the choice — at both political and marketing level - to present the consumer co-operatives as an interclass entity and not, as had often occurred previously, as solely for the working class. This was important for two reasons: firstly, new groups of consumers came to these shops and, secondly, in many cases the points of sale abandoned the Spartan appearance that had previously distinguished them because they were focusing with greater conviction on the middle class and not just the working and farm-labour classes.

During the years of fascism, the consumer co-operative movement was involved in a very important organizational innovation: the establishment of the Ente Centrale Approvvigionamenti ("Central Wholesale Society" - ECA, and from 1938 EICA), which we can consider the ancestor of the national consortium for collective purchases, namely the ANCC (later Coop Italia) ${ }^{51}$. The establishment of the organization, which occurred in 1927, was certainly

\footnotetext{
49 Brazda and Schediwy (1989).

50 Bludau (1968).

51 Vera Zamagni et al. (2004). See also Casali (1994, 2000).
} 
useful for the commercial modernization of the Italian consumer co-operative movement, and demonstrated the unmistakable intent of the regime to begin rescuing those large co-operatives that had been between 1921 and 1925. Even with all its limitations, including its still-limited range, the ECA represented the single purchase agency which co-operators had wanted since the nineteenth century, when many had begun looking with admiration upon the English CWS ${ }^{52}$. According to co-operative doctrine, this consortium of consumer co-operatives had to rise from below, that is to say from the communion of the efforts of the individual associations. In Italy, however, the ECA was the product of a rescue and standardization operation undertaken after the chaos of the preceding years, without any recognition of the need for democratization in the retailing sector. The creation of this consortium was strongly linked to the monetary policy of stabilizing the lira, because the main goal was to curb the consumer prices in order to preserve the purchasing power of Italians.

Regardless of these considerations, we deduce that the creation of ECA was a huge step towards the overall improvement of the consumer co-operative movement from a business point of view, and therefore an important "legacy" left by Italian fascism for the movement which flourished, after 1945, on foundations which were once again democratic.

\section{CONCLUSIONS}

The impact of fascist ideology and the fascist governments on the consumer co-operative movement must be considered in generally negative terms, even if there are some significant exceptions in the field of business organization and performance.

Fascism opposed the consumer co-operative movement for two reasons. First, co-operation was a democratic organization linked to anti-fascist political cultures (socialism, christian democratic, and democratic liberal) and secondly, it was a competitor of the private shopkeepers, who represented an electoral base that approved of fascism. Because of these points, the consumer co-operative movement was the subject of a disparaging press campaign that was accompanied by a series of blackshirt attacks and - on an institutional level - a series of legislative measures penalizing the movement; these were followed by the "conquest" of many businesses through pressure or the imposition of new administrators. The figures demonstrate an undeniable contraction in the consumer co-operative movement in fascist Italy.

52 Battilani (1999). 
However, there was no desire to close down permanently the consumer co-operatives. Rather, the fascists attempted to develop a new theory on the subject. The literature on this subject takes up thousands and thousands of pages, and dozens and dozens of monographs and reviews, all of which denigrate the old socialist and christian co-operation without managing to formulate any original reflection on fascist co-operation. In fact, this last entity was a particularly contradictory hybrid in which - on a theoretical level leader-worship merged with members' democracy, oligarchy clashed with participation, and free elections had to be reconciled with the desires of the top levels. It is not surprising, therefore, that against this weakness, the actual behaviour of the fascist or fascistized co-operation was equally controversial.

The fate of many consumer co-operatives was dependent on the conduct of the new pro-fascist administrators. In various cases they were accessories to fraudulent divestments, and were driven by the desire to exploit the co-operatives for self-enrichment. In other cases, the co-operative was used as an instrument to discriminate against anti-fascists and to provide employment to right-wing sympathizers, or also to serve as a "sounding board" for the regime's propaganda. However, in some situations the work of the new administrators took on a more modern entrepreneurial vision. This meant that certain consumer co-operatives became more efficient from a business point of view, grew through mergers, and became more orientated towards the middle class and therefore more modern because they were less politicized and less overloaded with social burdens, thus following the European pattern of the consumer co-operativism during the interwar period.

\section{Bibliography}

Alfieri, D. (1929). Premessa. In R. Scheggi (ed.). La cooperazione nell'Italia fascista (pp. IX-XVI). Milano: Alpes.

Arbizzani, L., Onofri, N. S. and Garotti, G. R. (1991). L'unione dei mille strumenti. Storia della cooperazione bolognese dal 1943 al 1956. Bologna: Editrice Emilia Romagna.

Basevi, A. (1953). Sintesi storica del movimento cooperativo italiano. Roma: Stab. Staderini.

Battilani, P. (1999). La creazione di un moderno sistema di imprese. Il ruolo dei consorzi nella cooperazione di consumo dell'Emilia-Romagna. Bologna: Il Mulino.

- (2005). I mille volti della cooperazione italiana: obiettivi e risultati di una nuova forma di impresa dalle origini alla seconda guerra mondiale. In E. Mazzoli and S. Zamagni (eds.). Verso una nuova teoria economica della cooperazione (pp. 97-139). Bologna: Il Mulino. 
Biagi, B. (1927). Il carovita e la cooperazione di consumo. Discorso pronunciato alla Camera dei Deputati l'11 marzo 1927. Roma: Tipografia della Camera dei Deputati.

Bludau, K. (1968). Nationalsozialismus und Genossenschaftswesen. Hannover: Verlag für Literatur und Zeitgeschehen.

Boccolari, G. and Ferretti, V. (eds.). (1987). La cooperazione "rossa" sotto la scure littoria. Il movimento cooperative reggiano nel periodo fascista. Reggio Emilia: Ist. Storico Socialista P. Marani.

Bof, F. (1995). La cooperazione in Friuli e nella Venezia Giulia dalle origini alla seconda guerra mondiale. Udine: Arti Grafiche Friulane.

Bosworth, R. J. B. (1998). The Italian Dictatorship: Problems and Perspectives in the Interpretation of Mussolini and Fascism. London: Arnold.

Brazda, J. and Schediwy, R. (1989). Introduction. In J. Brazda and R. Schediwy (eds.). Consumer Co-operatives in a changing world (pp. 13-42). Ginebra: International Co-operative Alliance.

Briganti, W. (ed.). (1978). Il movimento cooperativo in Italia. 1926-1962. Roma: Editrice Cooperativa.

Caroleo, A. (1986). Il movimento cooperativo in Italia nel primo dopoguerra (1918-1925). Milano: Franco Angeli.

Casadio, A. (2009). L'età delle illusioni. La cooperazione di consumo dalla Prima guerra mondiale al Fascismo. In A. Baravelli (ed.). Un secolo di cooperazione di consumo a Ravenna (1861-1980) (pp. 119-169). Ravenna: Angelo Longo Editore.

Casali, A. (1994). I consorzi cooperativi nella cooperazione di consumo italiana. Dall'Ufficio centrale di provvedimento di Vercelli alla Coop Italia, 1887-1993. Firenze: Consorzio cooperative di consumo, stampa.

- (2000). Per una storia di Coop Italia: Mario Cesari (1926-1968). Bologna: Il Mulino.

D’Attorre, P. P., Errani, P. L. and Morigi, P. (1988). La città del silenzio. Ravenna tra democrazia e fascismo. Milano: Franco Angeli.

Degl'Innocenti, M. (1981). Geografie e strutture della cooperazione in Italia. In G. Sapelli (ed.). Il movimento cooperativo in Italia. Storia e problemi (pp. 3-88). Torino: Einaudi.

Ditt, K. (1986). Le cooperative nel Terzo Reich. In M. Degl'Innocenti (ed.). Le imprese cooperative in Europa (pp. 282-307). Pisa: Nistri-Lischi.

Dowe, D. (1988). Le unioni di cooperative commerciali, agrarie e di consumo in Germania nel XIX e nel XX secolo. In M. Degl'Innocenti (ed.). Il movimento cooperativo nella storia d'Europa (pp. 271-88). Milano: Franco Angeli.

Fabbri, F. (1972). Angiolo Cabrini (1869-1937). Dalle lotte proletarie alla cooperazione fascista. Cooperazione e società, 1-2, 3-63.

(2009). Le origini della guerra civile. L'Italia dalla Grande Guerra al fascismo, 19181921. Torino: UTET.

Fairbairn, B. (1999). The Rise and Fall of Consumer Cooperation in Germany. In E. Furlough and C. Strickwerda (eds.). Consumers against Capitalism? Consumer Co-operation in Europe, North America and Japan, 1840-1990 (pp. 267-302). Lanham: Rowman \& Littlefield Publishers.

Fay, C. R. (1939). Co-operation at Home and Abroad: a Description and Analysis. London: P. S. King. 
Focarile, C. (1930). La funzione sociale della cooperazione fascista per il potenziamento della stirpe. Roma: Esperienza cooperativa.

Franceschelli, M. (1949). L'assalto del fascismo alla cooperazione italiana. (1921-1922). Roma: Ed. Coop.

Friberg, K., Vorberg-Rugh, R., Webster, A. and Wilson, J. (2012). The Politics of Commercial Dynamics: Cooperative Adaptations to Postwar Consumerism in the United Kingdom and Sweden, 1950-2010. In P. Battilani and H. G. Schröter (eds.). The Cooperative Business Movement, 1950 to the present (pp. 243-262). Cambridge: Cambridge University Press. Available at: https://doi.org/10.1017/CBO9781139237208.013.

Furlough, E. (1991). Consumer cooperation in France: the politics of consumption: 1834-1930. Ithaca: Cornell University Press.

Gheduzzi, C. (1934). La cooperazione svedese. Bologna: Azzoguidi.

Gide, C. (1922). Consumers' Co-operative Societies. New York: Alfred A. Knopf.

Giumelli, T. (1929). La cooperazione di consumo in Italia e direttive per il suo maggiore sviluppo. In R. Scheggi (ed.). La cooperazione nell'Italia fascista (pp. 87-90). Milano: Alpes.

Hilson, M. (2013). Consumer Co-operation and Economic Crisis: The 1936 Roosevelt Inquiry on Co-operative Enterprise and the Emergence of the Nordic 'Middle Way'. Contemporary European History, 22 (2), 181-198. Available at: https://doi.org/10.1017/ S0960777313000040.

Holyoake, G. J. (1857). The History of the Rochdale Pioneers. London: Trübner \& Co.

International Co-operative Alliance. (1940). Consumers' Cooperation under the Nazi Regime. New York: ICA.

Killingback, N. (1988). Limits to Mutuality: Economic and Political Attacks on Co-operation during the 1920s and the 1930s. In S. Yeo (ed.). New Views of Co-operation (pp. 207-228). London: Routledge.

Kluge, A. H. (1991). Geschichte der deutschen Bankgenossenschaften. Zur Entwicklung mitgliederorientierter Unternehmen. Frankfurt am Main: Fritz Knapp.

Kurzer, U. (1997). Nationalsozialismus und Konsumgenossenschaften: Gleichschaltung, Sanierung und Teilliquidation zwischen 1933 und 1936. Pfaffenweiler: Centaurus. Available at: https://doi.org/10.1007/978-3-86226-854-2.

Labadessa, R. (1928). Caratteri distintivi della impresa cooperativa. Roma: Grafia.

- (1931). La cooperativa. Idee e realtà. Roma: Cooperativa Ape. (1933). Il bilancio della cooperazione del consumo in Italia. Roma: Edizioni Enc.

Lama, E. (1933). La cooperazione italiana nella dottrina e nella pratica. Roma: Casa editrice Pinciana.

Leonardi, A. (ed.). (1991). Un ventennio difficile di cooperazione trentina. Il Sait dal 1926 al 1945. Rovereto: Pancheri.

Maddison, A. (2006). The World Economy. Paris: OECD. Available at: https://doi. org/10.1787/9789264022621-en.

Medina-Albaladejo, F. J. (2017). Consumer co-operatives in Spain, 1860-2010. In M. Hilson, S. Neunsinger and G. Patmore (eds.). A global history of consumer co-operation since 1850: movements and businesses (pp. 326-352). Leiden: Brill. Available at: https:// doi.org/10.1163/9789004336551_016. 
— and Pujol-Andreu, J. (2014). Cooperativas de consumo y niveles de vida, España 18651939: Una primera aproximación. Scripta Nova. Revista Electrónica de Geografía y Ciencias Sociales, 494. Available at: https://goo.gl/pHmxLe.

Menzani, T. (2009). Il movimento cooperativo fra le due guerre. Il caso italiano nel contesto europeo. Roma: Carocci.

Mitchell, B. R. (2003). International Historical Statistics. Europe, 1750-2000. New York: Palgrave Macmillan.

Nejrotti, M. (1984). Il movimento cooperativo di consumo nel Milanese (1918-1925). Storia in Lombardia, 3, 119-169.

- (1986). Fascismo: la cooperazione compressa e snaturata. In G. Sapelli and M. Degl'Innocenti (eds.). Cooperative in Lombardia dal 1886 (pp. 85-111). Milano: Unicopli.

Novy, K. (1988). Cultura ed edilizia popolare e cooperative. In M. Degl'Innocenti (ed.). Il movimento cooperativo nella storia d'Europa (pp. 287-297). Milano: Franco Angeli.

Pagano, L. (1930). La cooperazione nel fascismo: cenno ético. Napoli: Federazione regionale fascista delle cooperative.

Pantaleoni, M. (1922). Prefazione. In G. Preziosi. Uno Stato nello Stato. La Cooperativa Garibaldi della gente di mare (pp. 11-17). Firenze: Vallecchi.

Peruta, F. D. and Varni, A. (eds.). (1989). Pietra su pietra: storie di fornaciai e muratori a Bologna tra immagini e parole. Casalecchio di Reno: Grafis edizioni.

Piemontese, G. (1928). Le cooperative operaie di Trieste, Istria e Friuli. Roma: Edizioni delle Cooperative operaie di Trieste Istria e Friuli.

Preziosi, G. (1922). Uno Stato nello Stato. La Cooperativa Garibaldi della gente di mare. Firenze: Vallecchi.

Prinz, M. (2017). German Co-operatives: Rise and Fall, 1850-1970. In M. Hilson, S. Neunsinger and G. Patmore (eds.). A global history of consumer co-operation since 1850: movements and businesses (pp. 243-266). Leiden: Brill. Available at: https://doi. org/10.1163/9789004336551_013.

Setzer, J. (1989). The consumer co-operatives in Italy. In J. Brazda and R. Schediwy (eds.). Consumer Co-operatives in a changing world (pp. 819-897). Ginebra: International Co-operative Alliance.

Storchi, M. (1988). La cooperazione reggiana nel fascismo: strutture e gerarchie (1923-1934). In M. Degl'Innocenti, P. Pombeni and A. Roveri (eds.). Il PNF in Emilia Romagna: personale politico, quadri sindacali, cooperazione (pp. 65-73). Milano: Franco Angeli.

Thompson, E. P. (1966). The Making of the English Working Class. New York: Vintage Books.

Williamson, J. G. (1991). Inequality, Poverty, and History: Kuznets Memorial Lectures of the Economic Growth Center, Yale University. Oxford: Basil Blackwell.

Wrigley, E. A. (1990). Continuity, Chance and Change: The Character of the Industrial Revolution in England. Cambridge: Cambridge University Press.

Zamagni, S. and Zamagni, V. (2010). Cooperative Enterprise. Facing the Challenge of Globalization. Cheltenham: Edward Elgar. Available at: https://doi.org/10.4337/97818498 05667.

Zamagni, V. (1981). La distribuzione commerciale in Italia fra le due guerre. Milano: Franco Angeli. 
- and Fornasari, M. (1997). Il movimento cooperativo in Italia: un profilo storico-economico (1854-1992). Firenze: Vallecchi.

— Battilani, P. and Casali, A. (2004). La cooperazione di consumo in Italia. Bologna: Il Mulino.

Zavaroni, A. (1987). Malvossi e Marpioni dietro uno strano libello. 'La Valvola' (1902-09). l'Almanacco, 11, 25-36. 